\title{
EVALUATION OF MICROBIAL CONTAMINATION OF CHICKEN EGGS FROM DIFFERENT POULTRY FARMS IN AL ZAWIA REGION
}

\author{
Siham A. Ali ${ }^{1}$, Samira B. Abusiwi ${ }^{2}$, Sarah A. Haouissa ${ }^{3}$, Khaled Othman ${ }^{4}$, Sondos A. \\ $\mathrm{Azaz}^{5}$, Ibtesam O. Amer ${ }^{6}$ \\ 1,2,3,6 Faculty of Medical Technology, University of Sabratha. \\ ${ }^{4}$ Laboratory Department of Sabratha Teaching Hospital. \\ ${ }^{5}$ Department of Clinical Nutrition and Dietetics, College of Health Science, University of Sharjah. \\ 6ibtisam.amer@sabu.edu.ly
}

\begin{abstract}
Table eggs are consumed worldwide and are considered the most nutritious inexpensive source of protein that makes part of a healthy diet. Mistreated eggs have the ability to carry microorganisms or microbial toxins causing disease. The objective of this study is to determine how safe eggs are by identifying the bacterial load and pathogens resident on eggshells. Method: This study was conducted in the Microbiology Laboratory, Department of Biotechnology, Faculty of Medical Technology Sabratha. Shells of One hundred and fifty of chicken eggs collected from different poultry farms in region of Alzawia-Libya. Each egg shell membrane was swabbed and immediately transferred to appropriate broth media and incubated at $37^{\circ} \mathrm{C}^{\circ}$ for 18 hours. After incubation period a loop-full of broth media was transferred to agar media and incubated at $37^{\circ} \mathrm{C}$ for $48 \mathrm{hrs}$. Results: The result obtained showed microbial contamination was present on 135 (90\%) of all eggshells. Of the microorganisms present $43 \%$ was bacteria and $47 \%$ was fungi. Conclusion: It can be concluded that eggs got from the Libyan farm-hens can be contaminated and need for optimum hygienic conditions at the farm level to decrease the bacterial load.
\end{abstract}

Keywords: Egg Shells, Microorganisms Contamination, Food Poisoning.

\section{Introduction}

Food-borne illnesses are a major public health problem affecting developed as well as developing countries. Mistreated eggs have the ability to carry microorganisms or microbial toxins causing disease. However, poultry may carry bacteria that can cause illness; infected birds do not usually appear sick and even unbroken clean fresh shell eggs may contain harmful bacteria. (Barbara et al., 2010: Sabarinath et al, 2009). Human illnesses resulting from the consumption of poultry products contaminated with by Salmonella can be expensive for the poultry industry, governments, and can affect individuals. The total annual costs of medical care and lost productivity resulting from food-borne Salmonella infections of humans in the United States has been estimated at up 
to $\$ 3.5$ billion. A single serotype, $S$. Enteritidis, may account for as much as $\$ 870$ million of this total. (Andrew et al., 2004). Eggs can be contaminated with microorganisms such as bacteria and fungi. There is a variety of microbes with a wide range of pathogens such as Campylobacter jejuni, Listeria monocytogenes, Escherichiacoli, Yersiniaenterocolitica and Salmonella Spp (Ricke et al., 2001). These microorganisms can evade the defense mechanism of eggs and penetrate inside the egg. This process can increase the risk of foodborne illnesses or product spoilage (Board et al., 1995). International markets for poultry products are increasingly subject to restrictions based on food safety considerations. (Tan et al., 2012). The current study is to investigate the microbial quality of Libyan chicken eggs by identifying the microbial load on eggshells.

\section{Materials and Methods}

\section{Sample}

One hundred and fifty, ready for sale, poultry farm eggs were randomly picked and sent to the laboratory for examination. These poultry farms are located in the region of Alzawia, Libya

\section{Sample Processing}

Within six hours of collection, the egg samples were processed for the isolation of microorganisms from eggshells. For eggshell sampling, all eggs were processed regardless of their outer appearance like cracks on the eggshell, blood spots, or the presence of fecal material on the egg surface. Sterile cotton swabs dipped in sterile buffered peptone water (BPW) was used to swab the surface of the eggshell. The swabs were directly inoculated into $10 \mathrm{ml} \mathrm{BPW}$ in screw-capped bottles and incubated at $37^{\circ} \mathrm{C}$ for $24 \mathrm{~h}$ (Tan et al., 2012). At the end of incubation period a loop full of media was transferred to Blood Agar, Salmonella-Shegilla agar (Oxoid), Macconkey Agar (Oxoid), and Sabouroud Dextrose Agar (Oxoid), microorganisms were then isolated and identified (Collee et al., 1996).

\section{Isolation and Characterization}

Microorganisms were identified by culturing and incubation. The morphology of organisms was studied for size, shape, outline, color, and changes on various media. Bacteria was stained using the Gram stain method and examined using a light microscope of X100 with oil immersion. Biochemical tests to correct diagnosis included coagulase, catalase, and oxidase tests (Collee et al., 1996).

\section{Data Analysis}

Microsoft Office Excel 2007 was used to analyze and plot the collected data into charts.

\section{Results}

Out of 150 eggshells 135 (90\%) yielded growth of microorganisms. Amongst the isolated microorganisms, $43 \%$ was bacteria and $47 \%$ was fungi. Gram's staining showed that $23 \%$ 
isolates were Gram negative: whereas $20 \%$ isolates were gram-positive bacteria. The results revealed that the eggshells were contaminated with $20 \%$ Staphylococcus aureus, 5\% Pseudomonas aeruginosa, 5\% Escherichia coli, 3\% Klebsiella pneumonia, and 10\% Bacillus subtilis. Staphylococcus Spp. and Bacillus spp. were predominantly found associated with eggshells.

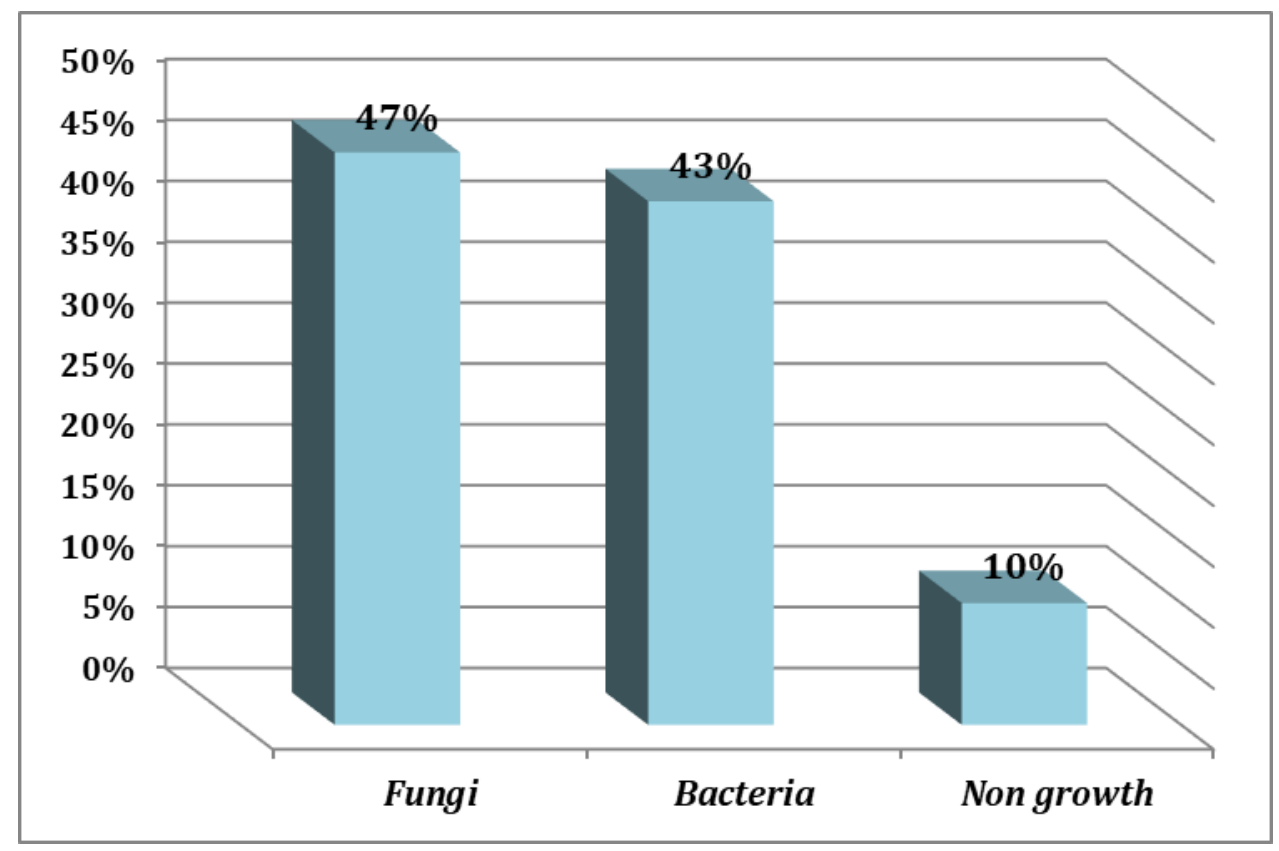

Figure (1): Percentage of Microbial Contamination of Egg Shells.

Out of all the pathogenic microorganisms, the viable Salmonella Spp was not noticed within the 150 eggshell surface swabs that were examined and grown on the SalmonellaShegilla agar selective media. The types of bacteria that were isolated from the eggshells are presented on Table (1) below.

Table (1): Percentage of Microbial Isolates from Egg Shells $(n=150)$

\begin{tabular}{|c|c|c|}
\hline \multirow{2}{*}{ Gram stain } & Types of organisms & $\begin{array}{c}\text { Percentage (\%) of isolated } \\
\text { organisms from eggshells }\end{array}$ \\
\hline Gram- positive & Staphylococcus aureus & $20 \%$ \\
\hline \multirow{4}{*}{ Gram- Negative } & Proteus spp & $10 \%$ \\
\cline { 2 - 3 } & Escherichia coil & $5 \%$ \\
\cline { 2 - 3 } & Pseudomonas aeruginosa & $5 \%$ \\
\cline { 2 - 3 } & Klebsiella pneumonia & $3 \%$ \\
\cline { 2 - 3 } & Salmonella spp & $0 \%$ \\
\hline \multirow{2}{*}{ Fungi } & fungi & $47 \%$ \\
\hline
\end{tabular}




\begin{tabular}{|c|c|c|}
\hline Non growth & & $10 \%$ \\
\hline \multicolumn{2}{|c|}{ Total } & $100 \%$ \\
\hline
\end{tabular}

\section{Discussion and conclusion}

Microbial contamination of eggs affects both public health and poultry industry (MAFF, UK, 2009). This study was undertaken to evaluate the microbial quality of eggs that are sold for human consumption in Libya. It has been found that the major contaminants are fungi and gram-negative bacteria that are belonging to the family Enterobacteriaceae. However, gram-positive Staphylococcus aureus was the only microorganism present on the eggshells. These observations are in agreement with the previous reports (Hang'ombe et al., 1999: Biomerieux, 2002). Eggs contamination could have occurred at either industry or household level because of suitable microbial growth conditions or because of improper handling. Bacterial contaminations might also be due to the contaminated clothes and hands of the poultry and market workers, (Loongyai et al., 2010).

The disinfection of eggs is extremely important as pathogenic contamination can have a disastrous effect on the community and population after consuming such contaminated eggs. Lack of standard structures and drainage systems in the market, and the presence of relatively high humidity could have contributed to the high microbial contamination. It has also been noticed that most retailers do not store eggs in refrigerators. Such conditions encourage microbial growth since the rate of egg spoilage depends on nutrient availability, temperature, storage, and handling, (Abdullah, 2010).

The isolated pathogenic microbes can cause severe health problems like diarrhea, nausea, and abdominal pain, (Al-Bahry et al., 2012). E. coli is a gram-negative bacterium of the family Enterobacteriacae and is a normal inhabitant of intestinal tract of birds, (Adday et al., 2009). It is one of the opportunistic pathogen responsible for a number of disease conditions such as yolk sac infection, air sac disease, prehepatitis, enteritis, omphalitis, and coligranuloma, colibacillosis. (Singleton et al., 1981: Kabuusu et al., 2003: Arathy et al., 2009). The researchers did not notice the presence of Salmonella on the external shell surface of all the eggs. However, the presence of the other microorganisms can be a major risk for the individuals who consume such eggs.

Because this study is not a good representative of the eggs available in the market and the breeding conditions vary from one breeder to the other, the researchers suggest that further actions need to be put in place to improve eggs hygiene and to achieve public health goals. Such actions can be in the form of educating hen breeders and making them abide to the hygienic practices as well as building up safe consumer handling and egg refrigeration at retail levels. If the eggs are held at the farm for more than 36 hours after production, it should be kept at or below $7.5^{\circ} \mathrm{C}$. The data highlights the need for optimum hygienic conditions at farm level to decrease the bacterial load in commercial chicken eggs in Libya. It can be concluded that eggs got from the Libyan farm-hens can be contaminated and might be a viable source of disease. 


\section{Acknowledgments TO}

- Mohamd Algelane, Abraheam Alkrade, and Ahmed Aftoha. Faculty of Medical Technology, University of Sabartha.

\section{References}

- Adday, S.; Ansah, T. G. S. K.; Dzoagbe, G. A.; Teye, S. \& Danquah, J. K (2009). Microbial Quality of Table Eggs Sold on Selected Markets in the Tamale Municipality in the Northern Region of Ghana. Livestock Res. For Rural Dev., 21.

- Al-Bahry SN, Mahmoud IY, Al-Musharafi SK \& Al-Ali MA (2012). Penetration of Spoilage and Food Poisoning Bacteria into Fresh Chicken Egg: A Public Health Concern. Global Journal of Bio-Science and Biotechnology. 1(1): 33-39.

- Andrew, C.; Voetsch, L.; Thomas, J.; Van Gilder, Frederick, J. A. 1.; Monica, M. F.; Sue, S.; Ruthanne, M.; Paul, R. C.; Valerie, C. D. \& Robert, V. T (2004). Estimate of Salmonella Incidence. [Food net Estimate of the Burden of Illnesscaused by Nontyphoidal Salmonella Infections in the United States. For the Emerging Infectionsprogram. CID:38 (Suppl 3) S127. Food net Working Groupa.

- Arathy S., Vanpee G., Belot G., Vanessa M., Claude D \& Ravindra N.S (2009). Bacterial contamination of commercial chicken eggs in Grenada, West Indies. West Indian Veterinary Journal. 9 (2): 4-7.

- Barbara Ingham and Ron Kean (2010). Egg Safety and the Backyard Flock University of Wisconsin-Madison and University of Wisconsin-Extension Adapted with permission from Home-Produced Chicken Eggs (Colorado State University Extension bulletin no. 9.377 (updated 5/12/2010) by M. Bunning and J. Avens. For information.

- Biomerieux, (2002). Identification System for Enterobacteriaceae and Other NonFastidious Gram-Negative Rods. Http://Www.Biomerieux.Com.

- Board, R.G. \& Tranter, H.S (1995). The microbiology of eggs. In: W. J. Stadelman and Coterill O. J. (eds). Egg Science and technology. 4th ed. Haworth Press Inc. New York.

- Collee, J. G.; Fraser, A. G.; Marmion, B. P. \& Simmons, A (1996). Practical Medical Microbiology. 14th.ed., Churchill Livingston, U.S.A.

- Gaungoo. Y \& Jeewon. R (2013). Effectiveness of Training among Food Handlers: A Review on the Mauritian Framework. Current Researchin Nutritionand Food Science, $1(1): 1-9$.

- Hang'ombe BM, Sharma RN, Tuchili LM \& Skjerve.O (1999). Isolation of bacteria from table eggs in Zambia. Indian J Ani Sci.69(6):445-47. 
- I. N. Abdullah. (2010) Isolation and identification of some bacterial isolates from table egg. Al-Anbar. J. ISSN: Vet. Sci., Vol.: 3 No. (2) .1999-6527.

- Kabuusu RM, McCann TJ \& Sharma RN (2003). Isolation of bacterial pathogens from table eggs in Grenada. J Carib Vet Med Assoc. 3(1):21-25.

- Loongyai W., Wiriya B. \& Sangsawang. N (2011). Detection of Salmonella and Escherichia coli in egg shell and egg content from different housing systems for laying hens. International Journal of Poultry Science. 10(2): 93-97.

- Ministry of Agriculture, Fisheries and Food (MAFF, UK) (2009). The Egg Quality Guide. Department for Environment Food and Rural Affairs. (DEFRA), http://archive.defra.gov.ukfoodfarm/food/industry/sectors/eggspoultry/eggs.html.

- Ricke S.C., Birkhold S.G. \& Gast R.K. (2001). Eggs and egg products. In compendium of methods for the microbiological examination of foods, 4th ed. Downes F. P. and Ito K. eds. American Public Health Association, Washington, D.C. 473-479.

- Sabarinath, VanpeeGuillaume, Belot Guillaume, Vanessa Mathew, Claude DeAllie \& Ravindra Nath Sharma. (2009) Bacterial contamination of commercial chicken eggs in Grenada, West Indies Arathy. West Indian Veterinary Journal. 9 (2) 4-7.

- Singleton, P. \& Sainsburg, D. (1981) Dictionary of Microbiology. International Ed. John Willey and Sons Ltd. Publication, New York. P. 425-426.

- Tan TC, Kanyarat K \& Azhar, ME. (2012) Evaluation of Functional Properties of Egg White Obtained from Pasteurized Shell Egg as Ingredient in Angel Food Cake.International Food Research Journal, 19(1): 303-308. 